11 Allain JP, Paul DA, Laurian Y, Senn D. Serological markers in early stages of human immunodeficiency virus infection in haemophiliacs. Lancet 1986;ii: 1233-6.

12 Centers for Disease Control. Classification system for human T-lymphotropic virus type IL/lymphadenopathy-associated virus infections. Ann Intern Med 1986;105:234-7.

13 Centers for Disease Control. Revision of the case definition of acquired immunodeficiency syndrome for national reporting. $M M W R$ 1985;34: $374-5$.

14 Peto K, Pike MC, Armitage DR, et al. Design and analysis of randomized clinical trials requiring prolonged observation of each patient. II. Analysis and examples. Br f Cancer 1977;35:1-39.

15 Haseltine WA. Replication and pathogenesis of the AIDS virus. Fourmal of AIDS 1988;1:217-40.

16 Pedersen C, Nielsen JO, Dickmeiss E, Jordal R. Early progression to the acquired immunodeficiency syndrome following primary human immunodeficiency virus infection. AIDS (in press)

17 Scott GB, Buck BE, Leterman JG, Bloom FL, Parks WP. Acquired immunodeficiency syndrome in infants. $N$ Engl J Med 1984:310:76-81.

18 Anderson KC, Gorgone BC, Marlink RG, et al. Transfusion-acquired human immunodeficiency virus infection among immunocompromised persons. Ann Intern Med 1986;105:519-27.
19 Cooper DA, Gold J, Maclean P, et al. Acute AIDS retrovirus infection. Lancet 1985;i:537-40.

20 Ho DD, Sarngadharan MG, Resnick L, Dimaszo-Veronese R, Rota TR, Hirsch MS. Primary human T-lymphotropic virus type III infection. Ann Intern Med 1985;103:880-3.

21 Tindall B, Barker S, Donovan B, et al. Characterization of the acute clinical illness associated with human immunodeficiency virus infection. Arch Intern Med 1988;148:945-9.

22 Weber JN, Rogers LA, Scott K, et al. Three-year prospective study of HTLV III infection in homosexual men. Lancet 1986; ; 1179-82.

23 Boyko WJ, Schenchter MT, Craib KJP, et al. The Vancouver lymphadenopathy-AIDS study: 7. Clinical and laboratory features of 87 cases of primary HIV infection. CMAf 1987;137:109-13.

24 Lange JMA, Parry JV, de Wolf F, Mortimer PP, Goudsmit J. Diagnostic value of specific IgM antibodies in primary HIV infection. AIDS 1988;2:31-5.

25 Pedersen C, Gerstoft J, Lindhardt B $\emptyset$, Sindrup J. Candida esophagitis associated with acute human immunodeficiency virus infection. F Infect Dis 1987; 156:529-30.

26 Rouse BT, Horohov DW. Immunosuppression in viral infections. Rev Infect Dis 1986;8:850-73.

(Accepted 12 April 1989)

\title{
Poor response to treatment of renal anaemia with erythropoietin corrected by iron given intravenously
}

\section{Iain C Macdougall, R David Hutton, Ivor Cavill, Gerald A Coles, John D Williams}

Institute of Nephrology, Cardiff Royal Infirmary, Cardiff CF2 1SZ Iain C Macdougall, MRCP, clinical research fellow Gerald A Coles, MRCP, consultant physician John D Williams, FRCP, senior lecturer

\section{Department of}

Haematology,

University of Wales

College of Medicine, Cardiff

R David Hutton, MRCPATH, senior lecturer

Ivor Cavill, FRCPATH, senior lecturer

Correspondence to: $\mathrm{Dr}$ Macdougall.

BrMed f 1989;299:157-8
Recombinant human erythropoietin is being used increasingly to treat renal anaemia in patients receiving haemodialysis and continuous ambulatory peritoneal dialysis. Its efficacy is undisputed; nevertheless, several centres have reported that some patients have responded poorly, slowly, or not at all. We report on five patients who responded poorly to such treatment until they were given iron intravenously.

\section{Case reports}

The five patients we describe participated in a study assessing the effect of erythropoietin on renal anaemia in 11 patients who were receiving regular haemodialysis. All five were treated with erythropoietin (Boehringer Mannheim) $240 \mathrm{U} / \mathrm{kg} /$ week intravenously and started prophylactic oral iron supplementation (ferrous gluconate $300 \mathrm{mg} /$ day; $35 \mathrm{mg}$ elemental iron) two weeks before the treatment with erythropoietin. Each patient had a normal serum ferritin concentration before treatment $(51,40,44,34$, and $37 \mu \mathrm{g} / 1$; normal range $15-300 \mu \mathrm{g} / \mathrm{l})$. Serum iron concentration and total iron binding capacity were monitored and the percentage saturation with transferrin calculated (serum iron concentration $(\mu \mathrm{mol} / \mathrm{l}) \div$ total iron binding capacity $(\mu \mathrm{mol} / \mathrm{l}) \times 100 \%)$.

The mean (SD) increase in haemoglobin concentration in the five patients was $25(13) \mathrm{g} / \mathrm{l}$ over the first eight weeks of treatment with erythropoietin compared with $45(20) \mathrm{g} / \mathrm{l}$ in six other patients in the study (all of whom had serum ferritin concentrations $>400$ $\mu \mathrm{g} / \mathrm{l}$ and transferrin saturations $>30 \%$ before treatment). Each of the five patients had an initial rise in haemoglobin concentration, which was not sustained; they were then given iron dextran intravenously (Imferon; $50 \mathrm{mg}$ elemental iron/ml) $1 \mathrm{ml}$ twice weekly during the last hour of dialysis.

The mean weekly rise in haemoglobin concentration during the four weeks before intravenous treatment with iron was $2.0 \mathrm{~g} / \mathrm{l}$; this rose to $5.3 \mathrm{~g} / \mathrm{l}$ after the treatment was started ( $p<0.005$, paired $t$ test), indicating more effective erythropoiesis even though the dose of erythropoietin was the same (table). Four of the patients had normal serum ferritin concentrations immediately before treatment with iron, suggesting adequate stores of iron in marrow; the remaining patient had a concentration at the lower limit of the normal range. In contrast, all five patients had low transferrin saturations $(<20 \%)$

\section{Comment}

Our data show a retarded response of haemoglobin concentration to erythropoietin, which was corrected by giving iron intravenously. Eschbach et al also reported on a patient in whom the response of the packed cell volume declined in the presence of an ample serum ferritin concentration $(518 \mu \mathrm{g} / \mathrm{l})$ but low transferrin saturation (13\%); this patient also responded to intravenous treatment with iron dextran. ${ }^{1}$

Erythropoietin seems to stimulate erythropoiesis to such an extent that the demand for iron can exceed the body's ability to release it from stores. This may lead to a functional iron deficiency, which can occur when serum ferritin concentrations are normal and iron can be detected in the marrow by staining.

Previous studies have suggested that stores of iron are adequate for erythropoiesis only if for every $50 \mathrm{~g} / \mathrm{l}$ rise in haemoglobin concentration a serum ferritin concentration of $\geqslant 100 \mu \mathrm{g} / \mathrm{l}$ is present. ${ }^{2}$ Patients who are particularly likely to develop functional iron deficiency, therefore, are those with serum ferritin

Clinical measurements in five patients receiving dialysis and treatment with erythropoietin before and after intravenous treatment with iron. Figures in parentheses are percentage transferrin saturations

\begin{tabular}{|c|c|c|c|c|c|c|c|c|c|}
\hline \multirow[b]{2}{*}{$\begin{array}{l}\text { Case } \\
\text { No }\end{array}$} & \multirow[b]{2}{*}{$\begin{array}{c}\text { Age } \\
\text { (years) }\end{array}$} & \multirow[b]{2}{*}{ Sex } & \multirow{2}{*}{$\begin{array}{l}\text { No of weeks of } \\
\text { treatment with } \\
\text { erythropoietin } \\
\text { when response } \\
\text { was poor }\end{array}$} & \multicolumn{3}{|c|}{ Before intravenous treatment with iron } & \multicolumn{3}{|c|}{ After intravenous treatment with iron } \\
\hline & & & & $\begin{array}{l}\text { Weekly increase } \\
\text { in haemoglobin } \\
\qquad(\mathrm{g} /)^{\star}\end{array}$ & $\begin{array}{l}\text { Serum } \\
\text { ferritin } \\
(\mu \mathrm{g} / \mathrm{l}) \dagger\end{array}$ & $\begin{array}{c}\text { Serum iron }(\mu \mathrm{mol} / \mathrm{l}) / \\
\text { total iron binding capacity } \\
(\mu \mathrm{mol} / \mathrm{l}) \dagger\end{array}$ & $\begin{array}{l}\text { Weekly increase } \\
\text { in haemoglobin } \\
(\mathrm{g} / \mathrm{l}) \ddagger\end{array}$ & $\begin{array}{l}\text { Serum } \\
\text { ferritin } \\
(\mu \mathrm{g} / \mathrm{l}) \S\end{array}$ & $\begin{array}{c}\text { Serum iron }(\mu \mathrm{mol} / \mathrm{l}) / \\
\text { total iron binding capacity } \\
(\mu \mathrm{mol} / \mathrm{l}) \oint\end{array}$ \\
\hline $\begin{array}{l}1 \\
2 \\
3 \\
4 \\
5\end{array}$ & $\begin{array}{l}26 \\
51 \\
22 \\
53 \\
52\end{array}$ & $\begin{array}{l}\mathbf{M} \\
\mathbf{F} \\
\mathbf{M} \\
\mathbf{M} \\
\mathbf{M}\end{array}$ & $\begin{array}{l}5-7 \\
4-8 \\
2-6 \\
3-6 \\
2-6\end{array}$ & $\begin{array}{l}2 \cdot 3 \\
1 \cdot 8 \\
0 \cdot 3 \\
2 \cdot 3 \\
3 \cdot 3\end{array}$ & $\begin{array}{l}16 \\
35 \\
32 \\
14 \\
31\end{array}$ & $\begin{array}{l}4 \cdot 8 / 54 \cdot 0(8 \cdot 9) \\
5 \cdot 0 / 57 \cdot 5(8 \cdot 7) \\
7 \cdot 8 / 44 \cdot 4(17 \cdot 6) \\
6 \cdot 7 / 54 \cdot 0(12 \cdot 4) \\
8 \cdot 5 / 50 \cdot 6(16 \cdot 8)\end{array}$ & $\begin{array}{l}8 \cdot 0 \\
3 \cdot 5 \\
3 \cdot 8 \\
4 \cdot 8 \\
6 \cdot 3\end{array}$ & $\begin{array}{l}17 \\
56 \\
21 \\
30 \\
16\end{array}$ & $\begin{array}{l}23 \cdot 2 / 59 \cdot 8(38 \cdot 8) \\
20 \cdot 0 / 53 \cdot 3(37 \cdot 5) \\
47 \cdot 0 / 53 \cdot 3(88 \cdot 2) \\
17 \cdot 5 / 56 \cdot 5(31 \cdot 0) \\
14 \cdot 0 / 57 \cdot 2(24 \cdot 5)\end{array}$ \\
\hline
\end{tabular}


concentrations $<100 \mu \mathrm{g} / \mathrm{l}$ before treatment with erythropoietin.

Transferrin saturation is a good indicator of the current balance of supply and demand of plasma iron, although it is an inadequate indicator of the amount of iron stored. ${ }^{23}$ In addition, Bainton and Finch showed that once the transferrin saturation falls below $16 \%$ iron supply for erythropoiesis may be inadequate. ${ }^{+} \mathrm{O}$ ur data also suggest that, during treatment with erythropoietin, monitoring of transferrin saturation is more reliable for detecting functional iron deficiency than is monitoring of serum ferritin concentration.

We believe that functional iron deficiency will become an increasing problem as treatment with erythropoietin is used more widely unless prophylactic iron is given parenterally when indicated - that is, when transferrin saturation falls below $20 \%$. This iron supplementation should also optimise the cost effectiveness of the drug.

We thank MCP Pharmaceuticals for financial help and for supplying erythropoietin; Ann Pugh and Richard Ellis for measuring serum ferritin concentrations; and Sara Hughes and David Trevett for assaying serum iron concentrations and total iron binding capacity.

1 Eschbach JW, Egrie JC, Downing MR, Browne JK, Adamson JW. Correction of the anemia of end-stage renal disease with recombinant human erythropoietin. $N$ Engl M Med 1987:316:73-8.

2 Cavill I. Clinics in haematology. Vol 11. London: W B Saunders, 1982:259-73.

3 Hussein S, Prieto J, O'Shea M, Hoffbrand AV, Baillod RA, Moorhead JF. Serum ferritin assay and iron status in chronic renal failure and hacmodialysis Serum ferritin assay and
BrMed $\mathcal{F} 1975 ; \mathrm{i}: 546-8$.

4 Bainton DF, Finch CA. The diagnosis of iron deficiency anemia. Am 7 Med 1964;37:62-70.

(Accepted 12 April 1989)

\section{Randomised trial of two strategies offering women mobile screening for breast cancer}

\author{
E M I Williams, M P Vessey
}

Department of Community

Medicine and General

Practice, Radcliffe

Infirmary, Oxford

OX2 6HE

E M I Williams, MB, senior registrar

M P Vessey, FFCM, professor

Correspondence to: $\mathrm{Dr}$ Williams.

BrMed f 1989;299:158-9
High compliance is an important prerequisite for effective population screening.' Responses to breast cancer screening of $85 \%$ and over have been achieved in Sweden ${ }^{2}$ and The Netherlands, ${ }^{3}$ but in the United Kingdom responses have been more modest: $60 \%$ in Guildford and $72 \%$ in Edinburgh. ${ }^{+}$These responses resulted from active invitation to participate, though the precise methods used have not been reported.

We determined whether compliance would improve if a letter of invitation contained a definite appointment for screening rather than an open ended request to make an appointment.

\section{Subjects, methods, and results}

A sample of 450 women aged 45-64 was identified from the age-sex registers of two general practitioners from one practice in Aylesbury and randomly allocated to receive either a letter with an appointment (group 1) or an open ended letter of invitation (group 2) for breast cancer screening. The letters were signed by the general practitioner and had, as far as possible, identical texts. At the screening office alternate appointments were allocated to the two groups.

Women in group 1 were asked to contact the screening service to cancel or alter appointments but not to confirm them. Women in group 2 were invited to return a form indicating convenient times; an appointment was then sent. Non-responders were sent a reminder after three weeks. Non-attenders from both groups were sent another appointment.

Both groups were comparable for age, previous screening (56 (30\%) and $69(34 \%)$ respectively had been screened before as volunteers), and where they lived.

Three invitations were accidentally sent to men. These and women who had moved, were duplicated on the register, and were known to have been screened recently were excluded. Nine women were inadvertently sent invitations instead of appointments, and one was sent an appointment instead of an invitation; they were also excluded. This left 188 women in group 1 and 204 women in group 2.

The table gives the main results. Women in group 1 had a significantly higher rate of response than women in group 2. Significant differences remained when the 10 women inadvertently sent the wrong letter were included according to both the received and the intended strategies. Compliance was improved in group 1 after every contact, though individual differences were not significant, and was higher than that in group 2 for all age groups, for previously screened women, and for previously unscreened women $(p<0 \cdot 05)$.

Response to invitation to breast cancer screening by appointment (group 1) or open ended invitation (group 2). Figures are numbers (percentages) unless stated otherwise

\begin{tabular}{lcc}
\hline & $\begin{array}{c}\text { Group 1 } \\
(\mathbf{n}=188)\end{array}$ & $\begin{array}{c}\text { Group 2 } \\
(\mathbf{n}=204)\end{array}$ \\
\hline Mean age (years) & $55 \cdot 4$ & $56 \cdot 1$ \\
Screened at: & & \\
$\quad$ First contact & $131(69 \cdot 7)$ & $131(64 \cdot 2)$ \\
Second contact & $26^{\star}(13 \cdot 8)$ & $19 \dagger(9 \cdot 3)$ \\
All other contacts & $5 \ddagger(2 \cdot 7)$ & $4 \rrbracket(2 \cdot 0)$ \\
\hline Total & $162 \|(86 \cdot 2)$ & $154(75 \cdot 5)$
\end{tabular}

*After cancellation (13) or non-attendance (13).

†After reminder.

$¥$ After both cancellation and non-attendance.

SAfter cancellation (2) or non-attendance (2)

Continuity adjusted $\gamma^{\prime}=6 \cdot 47 ; \mathrm{df}=1 ; \mathrm{p}=0.01$

From a total of 273 appointments issued to women in group 1, $45(24 \%)$ were unused through non-attendance; $32(17 \%)$ became available for reuse $-15(80 \%)$ after cancellation and $17(90 \%)$ after refusal or when letters were returned unopened. Unfilled and cancelled appointments in group 2 each accounted for under $2 \%$ (4) of the total.

\section{Comment}

This study shows that including an appointment in the invitation significantly enhances compliance with screening compared with an open ended invitation, confirming earlier findings reported for cervical screening. ${ }^{5}$ The improvement persisted across all contacts and age bands and remained regardless of screening history. This improvement may have arisen because a definite appointment may place more onus on women to attend.

The postage for group 1 cost about half that for group 2. Also, clerical staff reported that they found the appointment strategy more straightforward than the invitation strategy, though the work entailed was different. Non-responders are never given appointments with a system of open ended invitations. With pre-allocated appointments several remain vacant unless overbooking is allowed. Overbooking of preallocated appointments, however, remains to be tried, 